\title{
A Discourse Analysis of Deliberate Metaphors in President Xi's New Year Speeches from 2015-2017
}

\author{
Yuchen Li \\ College of Foreign Languages \\ Hunan University \\ Changsha, China
}

\author{
Di Wu \\ College of Foreign Languages \\ Hunan University \\ Changsha, China
}

\begin{abstract}
Deliberate metaphors (Steen 2008, 2010, 2011, 2013) are a valuable tool because they always trigger a conceptual change by the speaker inviting the addressee to look at the target domain from the perspective of the source domain. This paper explores deliberate metaphors in three speeches delivered from 2015 to 2017 by Chinese President with a main focus on the particular communicative functions realized by various forms of deliberate metaphors. The analysis shows how deliberate metaphors are used in order to communicate abstract political views to people.
\end{abstract}

Keywords-deliberate metaphor; political discourse; attention; conceptual change

\section{INTRODUCTION}

Metaphors used in political speeches have received great amount of attention in discourse analysis since Cognitive Metaphorical Theory (CMT) by Lakoff \& Johnson (1980, 1999) states that people are used to understanding abstract concepts in terms of concrete ones. The purpose in delivering a political speech is to communicate abstract knowledge in form of political terms which are not quite familiar to the audience. This provides a massive size of studies on analyzing metaphors in political discourse. Recent years has witnessed the success of a new classification of metaphors proposed by Steen $(2008,2010,2015,2017)$ which focuses on a particular kind of metaphor, deliberate metaphor, that has a crucial status in communicating in context. Deliberate metaphor works in discourse in a way that the speaker deliberately directs the addressee's attention and the addressee's perspective changes from the local topic to the source domain of the metaphor (Steen 2010: 58-60).

This study, based on Deliberate Metaphor Theory (DMT), takes a new approach on the nature and function of metaphors in political discourse and combines the analysis of deliberate metaphor with that of discourse analysis. In three new year speeches delivered by Chinese president $\mathrm{Xi}$ from 2015 to 2017 , deliberate metaphors are identified and their functions in the specific political contexts are analyzed. The results reveal how deliberate metaphors are used by $\mathrm{Xi}$ as tools for communicating political concepts to people and inspiring them. Firstly, the author will differentiate deliberate metaphors and non-deliberate metaphors in section II. Then the method used by the author to identify metaphors in general and deliberate metaphors in particular will be introduced in section III. After a detailed analysis of the nature and functions of deliberate metaphors in these speeches in section IV, the author will summarize findings in the conclusion in section $\mathrm{V}$.

\section{FORMS OF METAPHOR}

Within the theoretical framework of CMT, metaphor is considered as engaging not only language but also thought. This claim comes from the observation that people use many expressions metaphorically that belong to a more concrete or familiar domain (source domain) to talk about a more abstract or less familiar domain (target domain). With abundant linguistic evidence in this kind, scholars of CMT suggest a mapping between the source domain and the target domain on a conceptual level. Gibbs (1994: 261-264) noticed that some scholars assume that such cross-domain mappings are activated at every encounter of a linguistic metaphor. However, the assumption that every linguistic metaphor triggers a cross-domain mapping at conceptual level has received much criticism by scholars over the past 15 years (e.g. Bowdle \& Gentner 2005; Glucksberg 2001; Glucksberg $\&$ Haught 2006). The fact that not every linguistic metaphor would actually be processed as a metaphor on the conceptual level was termed "the paradox of metaphor" by Steen (2008: 214). Follow-up studies (Gentner \& Bowdle 2001; Bowdle $\&$ Gentner 2005) suggest that some metaphors, especially conventional metaphors which are the kernel for discussion within the framework of CMT (Lakoff \& Johnson 1980; Lakoff 1993), are quite often processed by categorization rather than by comparison. To resolve this paradox that language items can be processed as metaphorical on the linguistic level but may not be processed as metaphors on the conceptual level, Steen (2008, 2010, 2013, 2015, 2017) proposed a new model of metaphor that takes a third dimension into consideration to the current two-dimensional model which regards metaphor as a phenomenon of language and thought. The new communicative dimension makes it a possibility to study metaphors in discourse from a pragmatic perspective (Steen 2008: 221). Some metaphors are just "the way to say it" (Cameron 2003: 100) and do not exhibit a clear communicative function. In contrast, some metaphors are used deliberately in order to fulfill a particular kind of function in the discourse event and are termed as deliberate metaphor by Steen (2008). Deliberate metaphors are used to change the addressee's perspective on the referent or topic 
by the speaker inviting the addressee to look at the target domain from the perspective of the source domain. In a word, those metaphors are used actually as metaphors (Steen 2008).

The study of deliberate metaphors in political discourse is of great importance to uncover how politicians talk about abstract concepts. Given the nature of deliberate metaphors in discourse, we might presume that metaphors explicitly offer a more concrete or familiar domain that the addressee is supposed to relate as to understand an abstract or new political concept from the metaphor's source domain. So, it is expected that politicians use metaphors in deliberately as a tool to persuade or inspire the audience. In order to have a clear understanding whether deliberate metaphors in political discourse indeed have such functions, this paper aims at a detailed analysis of this kind of metaphors in its discourse context.

In this study, different functions of metaphors in political concepts will be analyzed with a special focus on deliberate metaphor. The author will also use either linguistic or contextual evidence to support the assumption that the respective metaphor is used deliberately. In order to fulfill this, the primary task is to identify a given lexical unit as metaphorical. The procedure for identifying metaphorrelated words (MRW) will be elaborated in the following section 3 .

\section{DATA AND RESEARCH METHOD}

Three speeches delivered by Chinese president at the New Year's Eve from 2016 to 2018 are chosen as the linguistic data and then analyzed for metaphor use. Metaphor identification is carried out on the basis of the Metaphor Identification Procedure VU (MIPVU, Steen et al. 2010) throughout the entire text of three speeches.

In a given text, the basic procedure of the MIPVU to find linguistic metaphors can be summarized in the following steps: firstly, the researcher examines the text on a word-byword basis, identifying the contextual meaning of each lexical unit. Then the contextual meaning is compared to the unit's other meanings by referring to a dictionary (The Contemporary Chinese Dictionary is used in this study). If the lexical unit has a more concrete and basic meaning, it is compared to the contextual meaning. If the contextual meaning is distinct from the basic meaning, but can be related to it by some kind of similarity, the lexical unit is marked as a metaphor related word (MRW, Steen et al. 2010: 25).

MIPVU accounts for both direct metaphors and indirect metaphors. Direct metaphors are usually used deliberately, because the lexical unit is always used in order to be compared to a more basic referent or topic in the text and thereby cross-domain mapping is activated. Such direct metaphors may exhibit in the form of a simile (A is like B), as in "Life is like a box of chocolate". The phrase a box of chocolate in this example directly refers to the chocolate in a food shop, rather than any transferred meaning of it. That is to say, there are no two senses of a box of chocolate in the example. The basic meaning of a box of chocolate is also its contextual meaning. The specific context of this sentence indicates that we are going to compare the literal meaning of a box of chocolate to the topic life. This kind of comparison makes similes as forms of direct metaphors. However, in a sentence like "He attacked my point of view", the meaning of the metaphorical unit attack can be understood as "to criticize" which is quite different from its basic sense "physically harm". The basic meaning is not the intended meaning here, but can be used to understand attack in the example via comparison with its contextual sense.

Also, the example "Life is like a box of chocolate" shows the deliberateness of metaphors. The linguistic form of " $\mathrm{A}$ is like B" sets up an explicit comparison between the two domains LIFE and CHOCOLATEBOX and then guide the addressee to think about life from the perspective of a box of chocolate, changing the addressee's view on the topic life. This is how deliberate metaphor works according to Steen (2008: 222).

In the following analysis, the author will focus on the metaphors that are used deliberately which are highlighted in both italics and bold print. Non-metaphoric expressions which are relevant to the contextual meaning of the deliberate metaphors are also highlighted using bold print only (without italics).

\section{ANALYSIS OF DELIBERATE METAPHORS IN POLITICAL DISCOURSE}

In this section, examples of different forms of potentially deliberate metaphor use are presented with detailed explanation of what linguistic and contextual clues there are to prove the deliberateness and discussion of the functions of the deliberate metaphors.

\section{A. Deliberate Metaphors in Talking about Government's Work}

In Xi's New Year speech delivered on December 31, 2017, there are two deliberate metaphors used when he commented on government work. In the excerpt below (example 1), Xi stressed the importance of each phase for the work of next three decades:

- (1) 九层之台, 起于累土。要把这个蓝图变为现实, 必须不驰 于空想、不鷘于虚声, 一步一个脚印, 踏踏实实千好工作。 (2017)

A nine-story tower begins with a pile of earth. To translate the blueprint into reality, we must neither rush upon fantasy nor be guided by the sound of falsehood. We shall work steadily and in a down-toearth manner.

The completion of any work requires patience and diligence on each and every phase of the process, not to mention a three-decade project. This is the target domain that $\mathrm{Xi}$ tries to communicate with people who might not have much knowledge about how government work runs. The fact is that people with not relevant work experience may have disappointment in the government when they know something is going to be done but do not see anything is going on in reality; for those who work for the government, they might rush too quickly at the beginning and fail in 
keeping up with the same pace in the long run. In order to communicate with people the importance of working steadily and modestly in the long run, Xi quotes Laotze's famous saying, an great philosopher in ancient China who talks about building a nine-story tower begins with a pile of earth. A comparison between building a tower and carrying out a long-term project is therefore established. Instead of saying how hard it is to complete the work, $\mathrm{Xi}$ chooses to compare it to the process of building a tower. Using the tower as a source domain for the process of carrying out a three-decade project in target domain is not conventional. Xi seems to actively create a new metaphor, the novelty of which is salient enough for the addressee to notice the source domain TOWER BUILDING and to actively compare it to the target domain. It allows people to think about government work that are hard to take effects immediately and hence very easy in showing discontent, in terms of something that is more familiar to them (the procedure of building a tower). The process of building a tower is easier to imagine and understand - it is more human experience-oriented. We are much more familiar with things in daily life. Thus, this comparison might help people to understand the process involved in taking a long period of time and requiring much patience and diligence.

In example (2), $\mathrm{Xi}$ talks about the difficulties in the reform and opening-up policy:

- (2) 2018 年, 我们将迎来改革开放 40 周年。改革开放是当代 中国发展进步的必由之路，是实现中国梦的必由之路。我们 要以庆祝改革开放 40 周年为契机, 逢山开路, 遇水架桥: 改 革的过程会遇到各种各样的问题。（2017）

2018 marks the 40th anniversary of China's reform and opening up policy. The policy is the only way for modern China to make progress in its development as well as to realize the Chinese dream. With the 40th anniversary of the reform and opening up policy as a turning point, we shall cut paths through mountains and build bridges across rivers, overcome all difficulties and carry reform through to the end.

The reform and opening-up policy is the only way for modern China to make progress in its development as well as to realize the Chinese dream. Over the past forty years, the Chinese has gone through many difficult situations and will do so in the future. There is not any country in the world which has the same experience for China to refer to, or any period of time in China's history which could be compared to this one. Therefore, China has to search for solutions to all sorts of problems all by itself independently, among which some might seem to be a bit of bold, or even radical that few people could understand well enough and criticisms are heard all the time. To explain how the government carries out the reform and deals with various kinds of difficulties, $\mathrm{Xi}$ compares the process of reform to a pioneer's work in an undeveloped zone who would make a path across a mountain or build a bridge over a river. Such comparison between a pioneer's work and China's reform helps people to understand that action takes priority in a situation with brand-new challenge. In order to make a way to an undeveloped zone, pioneers have to respond quickly when they face difficulties, and be confident in their decisions.
Nothing is better than acting quickly, though the action might seem to be lack in full consideration. Pioneer's work as the source domain is related to everyday life experience, and so the addressee can better understand the process of reform in the target domain. The metaphor is a conventional metaphor in terms of CMT, but it is not directly used as a metaphor in a linguistic form. The use of this metaphor in the speech shows that $\mathrm{Xi}$ attempts to invite people to think about the situation of a pioneer and therefore it is a deliberate use of metaphor.

\section{B. Deliberate Metaphors in Talking about Government's Role}

In Xi's New Year speeches in 2015 and 2016, he deliberately used two metaphors when talking about the role that the Chinese government plays in China. In the first one in example (3), China is now taking a long march in the new epoch:

- （3）上下同欲者胜。只要我们 13 亿多人民和哀共济，只要我 们党永远同人民站在一起, 大家撸起袖子加油千, 我们就一 定能够走好我们这一代人的长征。（2015）

- As one saying goes, "success comes to those who share in one purpose". So long as the 1.3 billion people pull together in forging ahead, the party stands identified with the people, and the nation remains mobilized for brand new endeavors, we will surely accomplish the Long March of our generation.

The concept of "long march" has been used frequently which is not something new to the Chinese who understand the phrase so well as a long and challenging task that the new generation is facing without the necessity of thinking back to 1930s when the CPC (the Communist Party of China) took a long march to in defending itself in the civil war. It is very familiar to Chinese in the context of CPC's leadership, hence the metaphorical use of "long march" is conceptual functioning as a subcategory of the noun "road" to refer to tasks full of challenge.

What is communicative rather than conceptual in this example is the metaphor used in first sentence. Cited from an ancient Chinese book Sun Tzu's Art of War, this sentence reminds people of a battlefield where the key to success is a tight connection of both generals and soldiers. Following such context, the audience compare the government and people in the target domain to a general and soldiers respectively in the source domain to understand the long march in the new generation, whose attention continues to be directed in the next sentence in the completion of portraying the CPC as a general who takes a modest and down-to-earth attitude, working hand in hand with his soldiers through all kinds of hardships. Therefore, an online cross-domain comparison is successfully established.

The second deliberate metaphor is in example (4) in which $\mathrm{Xi}$ quotes ancient Chinese poet $\mathrm{Du} \mathrm{Fu}$ :

- (4) “安得广厦千万间, 大批天下寒士俱欢颜！”340 万贫困 人口实现易地扶贫搬迁、有了温暖的新家，各类棚户区改造 开工数提前完成 600 万套目标任务。（2016） 
"If only I could get tens of thousands of mansions! I would house all the poor people who would then beam with smiles". As part of our poverty alleviation efforts, 3.4 million people have moved into new and warm homes, and the goal of upgrading 6 million housing units in run-down areas has been realized in advance.

$\mathrm{Xi}$ compares poverty-stricken people to those described in a poem by $\mathrm{Du} \mathrm{Fu}$, who is also well known as an idealist politician. The poet was influenced greatly by Confucius philosophy which emphasizes on benevolence and generosity of governance and expressed his dream of building mansions to shelter the poor as the primary task for a politician in this poem. It was one of the most famous poem in China and the meaning of it is well understood by all. Moreover, it is often used in a context when a gentleman decides to conduct something really good to improve people's living standards. When used in this speech, the poor people in the poem is now compared to poor people living in today as the fact that poverty is prevalent in every period of time in history, but none of which can be comparable to the current period because of the great achievement made by the government under the leadership of CPC. Therefore, an online comparison between the previous governments and the present government is set up indirectly and implicitly. The purpose of this deliberate metaphor is to tell people that the CPC always turns words into actions such as moving people into new homes. Xi deliberately uses this metaphor to guide audience to come to a conclusion that the Chinese government is not just aware of the need of people, but also responsible in fulfilling their tasks.

\section{Deliberate Metaphors in Talking about China's Role in the World}

What a role China plays in the world is a key issue in each year's speech. In the recent three years, Xi repeatedly uses the metaphor of NATION IS HUMAN when talking about China's status in the world's affairs in order to portray China as a responsible person. There are three deliberate metaphors regarding this, one in each year's speech. Take example (5) for detailed explanation:

- (5) 当前, 各方对人类和平与发展的前景既有期待、也有忧 虑, 期待中国表明立场和态度。天下一家。中国作为一个负 责任大国，也有话要说。中国坚定维护联合国权威和地位， 积极履行应尽的国际义务和责任, 信守应对全球气候变化的 承诺，积极推动共建 “一带一路”，始终做世界和平的建设 者、全球发展的贡献者、国际秩序的维护者。（2017）

At present, various sides have both expectations and worries about the prospect of peace and development for mankind, looking forward to China expressing its stand and attitude. The world is one big family. As a responsible major country, China has this to say: China will resolutely uphold the authority and status of the United Nations, conscientiously perform its due international obligations and responsibilities, keep its promises on global climate change, actively push forward the implementation of the Belt and Road Initiative, and always contribute to the building of world peace and global development, and the safeguarding of international order.

The NATION IS HUMAN metaphor has been used here in the phrases such as "responsible major country", "China has this to say", and all the duties that China determines to fulfill. To understand what China is going to do in terms of a person's duty does not require an online cross-domain mapping between nation (the target domain) and human (the source domain), so it is conceptual.

However, it is the sentence "The world is one big family" that matters in this context. In this sentence, there is a linguistic metaphor in an indirect form to compare the world to a family. A household include more than just one person, so as the world, in a way that everyone is important to each other that the whole family is closely tied up. This comparison is followed by a few sentences containing the conceptual metaphor of NATION IS HUMAN, which helps audience continue to think of China as a key member in this family, who has been and will be making contributions for the well-being of the family. During reading the whole part, an online cross-domain mapping between an abstract concept of a world consisting of many countries in the target domain and a concrete image of a family in the source domain is set up, and the image of China as a big brother in the figurative family who takes responsibility, keeps his promises to the end, and protects the other members is successfully delivered to the audience. Therefore, "the world is one big family" is a deliberate use of metaphor to have communicative functions. When putting in front of the sentences containing conceptual metaphors, this deliberate metaphor has its effect on portraying China as a responsible big brother; if put behind these sentences, the comparison will not trigger an online cross-domain mapping.

In addition to the comparison between the world to a family, there is another kind of deliberate metaphor used by $\mathrm{Xi}$ when talking about China's role in the world in example (6):

- (6) 世界那么大, 问题那么多, 国际社会期待听到中国声 音、看到中国方案，中国不能缺席。面对身陷苦难和战火的 人们，我们要有悲悯和同情，更要有责任和行动。中国将永 远向世界敞开怀抱，也将尽已所能向面临困境的人们伸出援 手，让我们的 “朋友圈” 越来越大。（2015）

The world is too big, and challenges are too many, to go without the voice from China being heard, without solution ideas from China being shared, without the involvement of China being needed. To those suffering from hardships and wars, we not only express our sympathy and solidarity, but will also take duty bound actions to provide help. China will, as always, open its arms to embrace the world, and offer its helping hands to those in needs. Our circle of friends will grow bigger.

Besides the conceptual metaphor NATION IS HUMAN in the phrases such as voice, express our sympathy and solidarity, take duty bound actions to provide help, open its arm, and offer its helping hands, there is a deliberate use of metaphor in the last sentence. The metaphorical phrase "circle of friends" comes from WeChat, a popular social app 
in China. Designed in 2008 and soon becoming the leading communicative tool in the country, WeChat introduced the concept of "circle of friends" to the Chinese because people often share their moments of daily life in forms of texts and pictures to and receive likes or comments from friends. The more friends there are, the more likes or comments they will receive; the less, the fewer. Since WeChat is a new thing, the concept of "circle of friends" in Chinese is quite new and used in limited context. When used here, it is a novel metaphor which activates the audience's knowledge about posting and giving likes on WeChat and triggers a crossdomain mapping between an abstract domain of the international affairs in the world and a more concrete domain of social network on the internet. To understand China's role in the world in terms of social app in this deliberate metaphor together with the NATION IS HUMAN metaphor in previous sentences, the audience feels much closer to other countries and more inclined to arrive at agreement of offering help to those in need.

\section{CONCLUSION}

Deliberate metaphors are used in order to communicate abstract concepts in terms of more concrete ones. In detailed discussion of each example in this paper, the author found that deliberate metaphors can be multifaceted and come in different forms - from direct and novel metaphors to indirect ones. Moreover, this study demonstrated that deliberate metaphors stand out from non-deliberate metaphors and fulfil various functions in political discourse for conveying political concepts.

\section{REFERENCES}

[1] B. Bowdle, and D. Gentner, "The Career of Metaphor," Psychological Review, 112 (1), 2015, pp. 193-216.

[2] D. Gentner, and B. Bowdle, "Convention, form, and figurative language processing," Metaphor \& Symbol, 16 (3\&4), 2001, pp. 223248.

[3] G. Lakoff, "The contemporary theory of metaphor," in Metaphor and Thought, A. Ortony, Ed. New York, 1993, pp. 202-251.

[4] G. Lakoff, and M. Johnson, Metaphors We Live By, The University of Chicago Press: Chicago, 1980.

[5] G. Lakoff, and M. Johnson, Philosophy in the Flesh: The Embodied Mind and Its Challenge to Western Thought, Basic Books: New York, 1999.

[6] G. Steen, The paradox of metaphor: why we need a three-dimensional model of metaphor, Metaphor \& Symbol, 23(4), 2008, pp. 213-241.

[7] G. Steen, "When is metaphor deliberate?" In Selected Papers from the 2008 Stockholm Metaphor Festival, C. Alm-Arvius, N.L. Johannesson, and D. Minugh Eds. Stockholm, 2010, pp. 43-63.

[8] G. Steen, "What does 'really deliberate' really mean? More thoughts on metaphor and consciousness," Metaphor in the Social World, 1(1), 2011, pp. 53-56.

[9] G. Steen, "Deliberate metaphor affords conscious metaphorical cognition," Journal of Cognitive Semiotics, V(1-2), 2013, pp. 179197.

[10] G. Steen, "Developing, testing and interpreting Deliberate Metaphor Theory," Journal of Pragmatics, 90, 2015, pp. 67-72.

[11] G. Steen, "Deliberate Metaphor Theory: basic assumptions, main tenets, urgent issues," Intercultural Pragmatics, 14(1), 2017, pp. 1-24.

[12] L. Cameron, Metaphor in Educational Discourse, Continuum: London/New York, 2004.
[13] R.W. Gibbs, The Poetics of Mind: Figurative Thought, Language, and Understanding, Cambridge, 1994

[14] S. Glucksberg, Understanding Figurative Language: From Metaphors to Idioms, Oxford, 2001

[15] S. Glucksberg, and C. Haught, "On the relation between metaphor and simile: when comparison fails," Mind \& Language, 21(3), 2006, pp. 360-378. 